\title{
Is the effectivity of copper ions treatment of milk enough to block Mycobacterium avium subsp. paratuberculosis infection in calves?
}

\author{
Pamela N. Steuera, Carlos Tejeda ${ }^{a}$, Manuel Moroni ${ }^{b}$, \\ Juan P. Soto ${ }^{\mathrm{c}}$, Miguel A. Salgado ${ }^{\mathrm{a}}$
}

\begin{abstract}
Milk is an important transmission route of Mycobacterium avium subsp. paratuberculosis (MAP) for dairy calves. Given its resistance to pasteurization, alternative milk treatments are needed to control MAP transmission via milk. The present study reports the evaluation of a novel milk decontamination treatment based on copper ions as a means of preventing infection in dairy calves. Ten newborn calves were assigned to one of two experimental groups $(\mathrm{n}=5)$ which were studied for 1 year. The first group was fed milk naturally contaminated with MAP and the second one received the same milk but after being treated with copper ions. In both groups, milk MAP load was estimated. The progression of the infection was monitored monthly and at the end of the study, calves were euthanised, and tissue samples were examined both grossly and by histopathology. The treatment of milk with copper ions significantly reduced the number of viable MAP. Faecal shedding of MAP was observed in both study groups, but the calves fed naturally contaminated milk began to shed MAP earlier. Only calves fed copper-treated milk showed histopathological evidence consistent with MAP infection. The latter offers more questions than answers, and maybe the presence of a more tolerant and virulent MAP strain could be the final answer to this situation.

Key words: MAP, milk, treatment, copper, calves, infection, control.
\end{abstract}

\section{INTRODUCTION}

Mycobacterium avium subsp. paratuberculosis (MAP) is the causative agent of a highly contagious chronic infectious disease known as paratuberculosis or Johne's disease. It affects mainly domestic and wild ruminants but also affects a wide range of non-ruminant animal species (Greig et al 1991, Harris and Barletta 2001) including humans (Chiodini et al 2012). MAP is highly resistant to adverse environmental conditions (low $\mathrm{pH}$, high salt concentrations, and chlorine) (Whan et al 2001), being able to survive in the environment for more than a year (Salgado et al 2013) and can also survive pasteurisation (Grant et al 1996, Grant et al 2005).

Although the faecal-oral route is the main way of infection transmission (Sweeney 2011), the pathogen may also spread through colostrum and milk (Sweeney 1996) and newborns are at the greatest risk of infection, especially when consuming milk contaminated with MAP (Windsor and Whittington 2010, Sweeney 2011). Due to the above mentioned, the control of paratuberculosis infection is very challenging and many of the measures commonly adopted to prevent the newborn's infection (e.g. use of pasteurised milk or milk replacer) do not assure a pathogen-free milk diet (Grant et al 2005, Grant et al 2017).

Received: 02.10.2020.

Accepted: 26.01.2021.

${ }^{a}$ Instituto de Medicina Preventiva Veterinaria, Facultad de Ciencias Veterinarias, Universidad Austral de Chile, Valdivia, Chile.

bInstituto de Patología Animal, Facultad de Ciencias Veterinarias, Universidad Austral de Chile, Valdivia, Chile.

'Prolesur, Osorno, Chile.

*Corresponding author: MA Salgado; Saelzer Building $5^{\circ}$ Piso, Campus Isla Teja, PO Box 567, Valdivia, Chile; miguelsalgado@uach.cl
The latter invited us to explore other alternatives to control MAP infection or to decrease its load in colostrum and milk. We paid attention to the profuse evidence showing the antimicrobial properties of copper and copper alloys. Copper surfaces can eliminate bacterial pathogens, viruses and fungi (Faúndez et al 2004, Wilks et al 2005, Noyce et al 2006 ${ }^{\mathrm{a}}$, Noyce et al 2006 $6^{\mathrm{b}}$, Grass et al 2011). Recently, using an in vitro model, we showed that the use of a copper ions treatment protocol significantly reduced MAP load in PBS (Steuer et al 2018). Later, we observed that copper ions decreased viable MAP numbers in milk in a similar way (Steuer et al 2020). However, some MAP cells apparently either tolerate the effects of copper ions or repair sub-lethally damaged cells during subsequent liquid culture (Steuer et al 2018, Steuer et al 2020).

Due to the promising experimental results of the copper ions treatment, we aimed to estimate the effectiveness of this novel treatment in terms of its success to block infection transmission or the progression of MAP infection in newborn calves fed with MAP naturally contaminated milk and treated with copper ions.

\section{MATERIAL AND METHODS}

Between November 2017 and October 2018, a oneyear longitudinal study was carried out in the Los Ríos Region, south of Chile. Based upon the animal welfare concern, since animals were exposed-infected and euthanised by the end of the experiment, the suitable facilities and the economic considerations, ten newborn calves were acquired from one small dairy herd (less than 100 animals), located in the Los Ríos region. This herd was selected because it had a history of confirmed negative paratuberculosis diagnostic results and absence of clinical cases. The 10 newborn calves were separated 
from their mothers before they were able to nurse on their own, fed colostrum from their own dam (first day of life) in a hygienic environment, and kept in individual pens. Once calves had a dry hair coat and navel cord, according to international animal regulations regarding animal welfare (Albright et al 2007), they were transferred to an experimental farm (a completely separate farm also located in the Los Ríos region), where they were randomly separated in 2 experimental groups. Technical staff entered the pens rigorously wearing clean coveralls, boots, and gloves exclusively for each pen, as well as they also used exclusive items to keep the pen clean to eliminate the risk of cross-contamination.

In parallel, we managed the temporary use of 5 infected and infectious lactating cows from a herd with a history of confirmed high paratuberculosis infection rate and several clinical cases per year. These 5 infected and infectious cows were confirmed as MAP positive by faecal culture in the BACTEC-960 system and anti-MAP antibodies by an ELISA test and therefore selected as nurse dams, transferred to the experimental farm, and the milk collected was used to feed the calves. This naturally contaminated milk was sampled once a week for a total of 12 weeks (period of milk diet supply) in order to detect MAP and estimate its load.

After collecting the naturally contaminated milk used to feed calves in one of the groups, this milk was decontaminated using a copper treatment adapted from Steuer et al (2018) and modify to field conditions. Briefly, the treatment device consisted of a stainless-steel receptacle containing $20 \mathrm{~L}$ of milk naturally contaminated with MAP in which two high purity copper cylinders were immersed. The copper cylinders were stimulated with a low voltage $(24 \mathrm{~V})$ electric current $(3 \mathrm{~A})$ to quickly release copper ions for 8 minutes. The receptacle was carefully shaken during treatment to allow constant mixing.

The 10 newborn calves were randomly assigned to one of two experimental groups and each animal received a dairy diet of 4L/day for 12 weeks. Group A (n=5) received milk naturally contaminated with MAP and group $\mathrm{B}(\mathrm{n}=5)$ was fed with the same MAP-infected milk but that was treated with copper ions. Each group of calves was kept in separated pens (without direct contact between groups) until the end of the study period (1 year). From the fourth month and until the end of the study period, the calves had access from their collective pens to a paddock (properly separated between pens), which guaranteed the minimum surface for each one in terms of animal welfare (minimum than $2.6 \mathrm{~m}^{2}$ per animal) (Stull et al 2008). During the first 12 weeks, the calves were also offered hay, growth concentrate and water ad libitum. Finally, from 12 weeks onwards, the animals also received grass silage. From each calf, faecal samples were taken monthly and processed for culture as described below.

MAP detection and bacterial load in naturally contaminated milk samples, before and after treatment with copper ions, were estimated once a week during the first 12 weeks and once a month during the entire study period using the genome equivalent principle, according to a published protocol (Dzieciol et al 2010) based on the concentration of MAP DNA measured in a Nanoquant spectrophotometer (TECAN group, Männedorf, Schweiz) adjusted for a $10^{8}$ dilution and the number of copies of the IS900 target gene, and having the reference of the molecular weight of the genome of MAP ATCC strain 19698 to establish a standard curve for estimation of MAP numbers in the samples by Roche 2.0 realtime PCR, according to the equation shown by Steuer et al (2019).

The infectious process and the progression of MAP infection were evaluated in vivo before the first milk intake and then monthly by MAP faecal shedding (culture of faecal samples in the BACTEC-MGIT 960 liquid culture system, Becton Dickinson, Sparks, MD). Between 5 to 10 $\mathrm{g}$ of faecal material was obtained from all calves directly from the rectum using individual palpation sleeves. The samples were transported to the Laboratory of Infectious Diseases at the Institute of Preventive Veterinary Medicine, Faculty of Veterinary Sciences, Universidad Austral de Chile. Faecal samples were kept at room temperature until processing within the following 2 days.

To complement the bacteriological analyses and to determine if a positive culture corresponded to an active infection or to a transitory MAP passage through the digestive tract, a necropsy was performed at the end of the study period (12 months) on all calves to find lesions consistent with MAP infection in tissues, followed by a histopathological study of the samples obtained. The necropsy was blind as to the type of treatment of the animals. The calves were euthanised by an expert veterinarian pathologist using a retained projectile pistol, following the criteria of the Bioethics Committee of the Research and Development Department (DID) of the Universidad Austral de Chile (validation report $\mathrm{N}^{\circ}$ 263-2016). Ileum, mesenteric lymph nodes (MLN), and ileocecal valve were taken from each animal and placed in $10 \%$ formalin for subsequent histopathological and bacteriological analyses. Also, ileum and MLN samples were cultured in the BACTEC-MGIT 960 system for MAP detection, as mentioned previously.

After a minimum of 24 hours of fixation, the tissues were dehydrated through graduated alcohols and embedded in paraffin wax. Then, $5 \mathrm{~mm}$ thick sections were cut and stained with hematoxylin-eosin. Besides, serial sections of ileum samples (mucosa) were stained with Ziehl-Neelsen stain to observe the presence of acid-fast bacilli.

Differences in MAP load (using the $\log _{10}$ of the bacterial load estimates) between copper-treated and untreated milk samples and faecal samples between both calf groups were estimated using the Wilcoxon-Mann-Whitney test. Statistical analyses were run using the statistical software $\mathrm{R}$ version 3.6.3 ( $\mathrm{R}$ core team 2020). 


\section{RESULTS AND DISCUSSION}

The present study reports the application of a milk decontamination treatment based on copper ions at the field level, with a one-year follow-up of two groups of newborn calves that received different dairy diets, to evaluate the course of MAP infection.

A significantly $(P<0.01)$ higher MAP load was observed in the untreated milk samples when compared to the copper-treated ones. Bacterial load estimation by genome equivalent principle on naturally contaminated milk samples showed a MAP load between 5.2 $\times 10^{2}$ and $6.46 \times 10^{4}$ DNA copies (genome equivalents) per mL of milk. In most of the copper-treated milk samples, no presence of MAP DNA was detected except for two occasions. Therefore, we dare to speak of viable MAP in untreated copper milk, because there is convincing published evidence showing that copper produces significant damage on bacterial DNA, making it non-amplifiable (Steuer et al 2018, Warnes et al 2010, Weaver et al 2010).

We cannot rule out that feedstuff could have been contaminated with faecal material from infected animals. As for MAP faecal shedding, we did not observe significant MAP faecal load differences between groups. All calves shed MAP sporadically in their faeces at least once during the follow-up period. The latter does not necessarily mean an active infection, but also a transient passage of the pathogen through the intestine (Corbett et al 2019). However, the group of calves naturally exposed to MAP infection (group A) began to shed earlier (when they were still consuming milk diet) than the other group. This agrees with Mitchell et al (2012), who concluded that natural infections may have a much shorter time to shedding than generally assumed. On the other hand, group B showed positive faecal results from the fifth month of the study.

No calves had positive cultures for MAP from fresh tissues collected at necropsy. However, calves from both groups had gross pathology evidence consistent with a
MAP infection (table 1), e.g. enlarged lymph nodes adjacent to the last third of the jejunum and ileum (figure 1A) lymphangitis in the ileum's serosa (figure 1B), red and edematous ileocecal valve (figure $1 \mathrm{C}$ ), and thickening and folding of the ileal mucosa (figure 1D). Interestingly, only calves from group B had Langhans-type cells in the lamina propria of the jejunum and ileum (table 2; figures 2A and 2B). Although it was not possible to demonstrate the presence of acid-fast bacilli in any of the tissues sampled, the presence of Langhans type giant cells in the lamina propria at any level of the gastrointestinal tract should make us suspect a MAP infection, even if no acid-fast bacilli are found (Manning and Collins 2001). The latter could be interpreted as a paucibacillary infection, caused by consumption of a dairy diet containing MAP loads significantly lower than a highly faecal-contaminated environment from infected animals. This point agrees with Mitchell et al (2012), who concluded that the initial MAP dose is the most important factor in infection progression. Also, Mortier et al (2014) observed that in young calves, a high inoculation dose resulted in more pronounced lesions than a low inoculation dose.

Another possible explanation is what Mehtar et al (2008) described when Mycobacterium tuberculosis was exposed to copper, and some strains that resist this treatment were those that showed more virulence in experimental laboratory animals. Supporting the latter, Wolschendorf et al (2011) also demonstrated that copper resistance is associated with pathogen virulence. Having the above mentioned in mind, maybe the copper concentrations and/ or the exposure time ( $8 \mathrm{~min}$ ) may not have been enough to eliminate MAP in raw milk. Interestingly, what we know as a fact is that we previously demonstrated in PBS and also in milk, that although copper ions are highly effective in reducing MAP numbers, some MAP cells survived (Steuer et al 2018, Steuer et al 2020).

Although the number of calves in the present study represented the most challenging task to fulfil, we combined

Table 1. Anatomopathological findings.

\begin{tabular}{cccccc}
\hline Group & Calf & $\begin{array}{c}\text { Thickening and folding of the } \\
\text { ileal mucosa }\end{array}$ & $\begin{array}{c}\text { Enlarged mesenteric } \\
\text { lymph nodes }\end{array}$ & $\begin{array}{c}\text { Lymphangitis in the } \\
\text { ileum's serosa }\end{array}$ & $\begin{array}{c}\text { Edematous ileocecal } \\
\text { valve }\end{array}$ \\
\hline A & 270817 & Yes & Yes & Not observed & Yes \\
A & 050917 & Yes & Yes & Yes & Yes \\
A & 300917 & Yes & Yes & Yes & Not observed \\
A & 011017 & Yes & Yes & Not observed & Yes \\
A & 021017 & Yes & Yes & Yes & Not observed \\
B & 311017 & Yes & Yes & Not observed & Not observed \\
B & 011117 & Yes & Yes & Not observed & Not observed \\
B & 021117 & Yes & Yes & Not observed & Not observed \\
B & 031117 & Yes & Yes & Yes & Not observed \\
B & 041117 & Yes & Yes & Not observed & Not observed \\
\hline
\end{tabular}




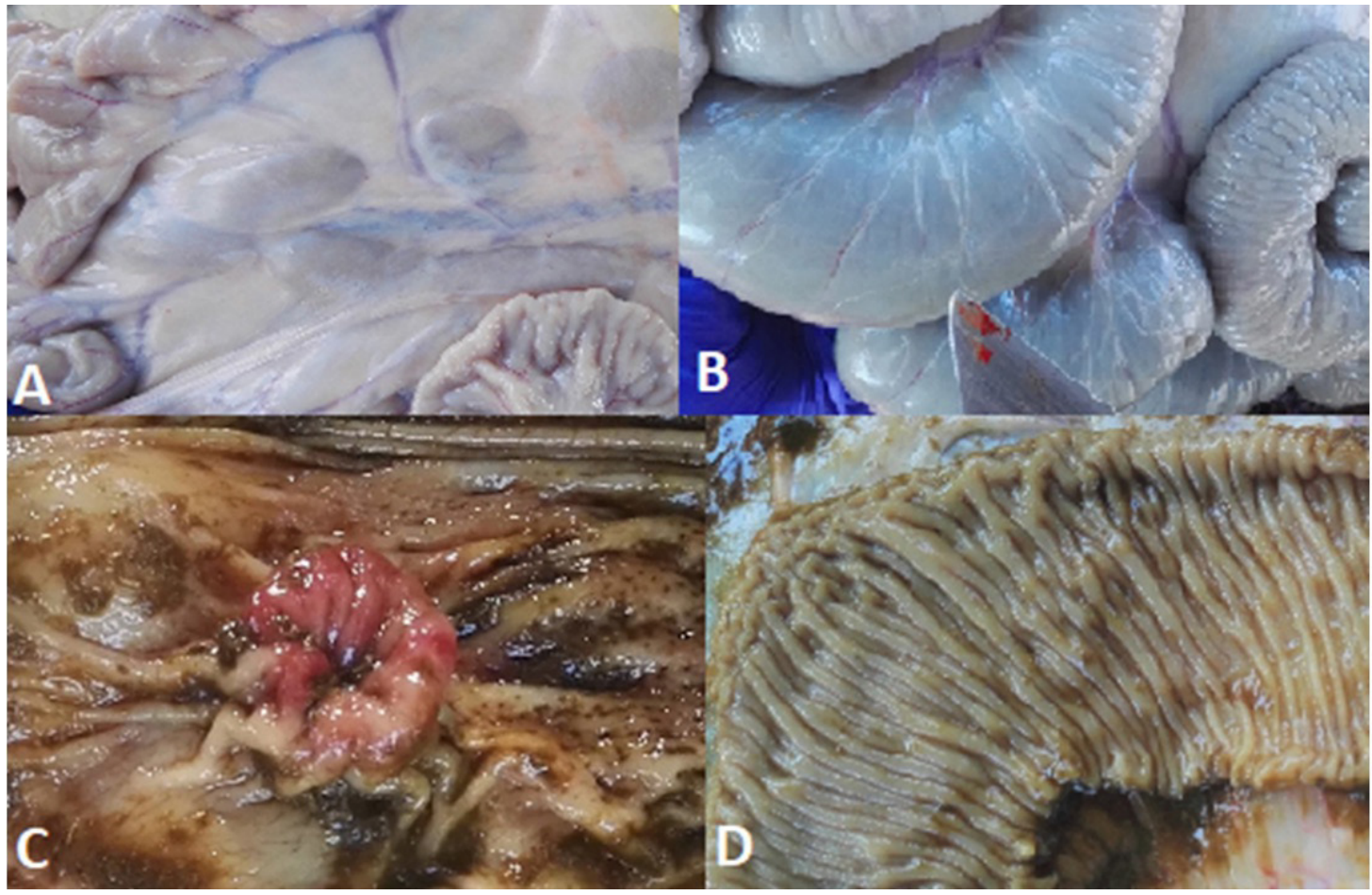

Figure 1. Findings observed after post-mortem examination of calves from groups A and B. A: enlarged lymph nodes adjacent to the last third of the jejunum and ileum, calf \#031117, group B. B: lymphangitis in the ileum's serosa, calf \#300917, group A. C: reddened and edematous ileocecal valve, calf \#270817, group A. D: thickening and folding of the ileal mucosa, calf \#011017, group B.

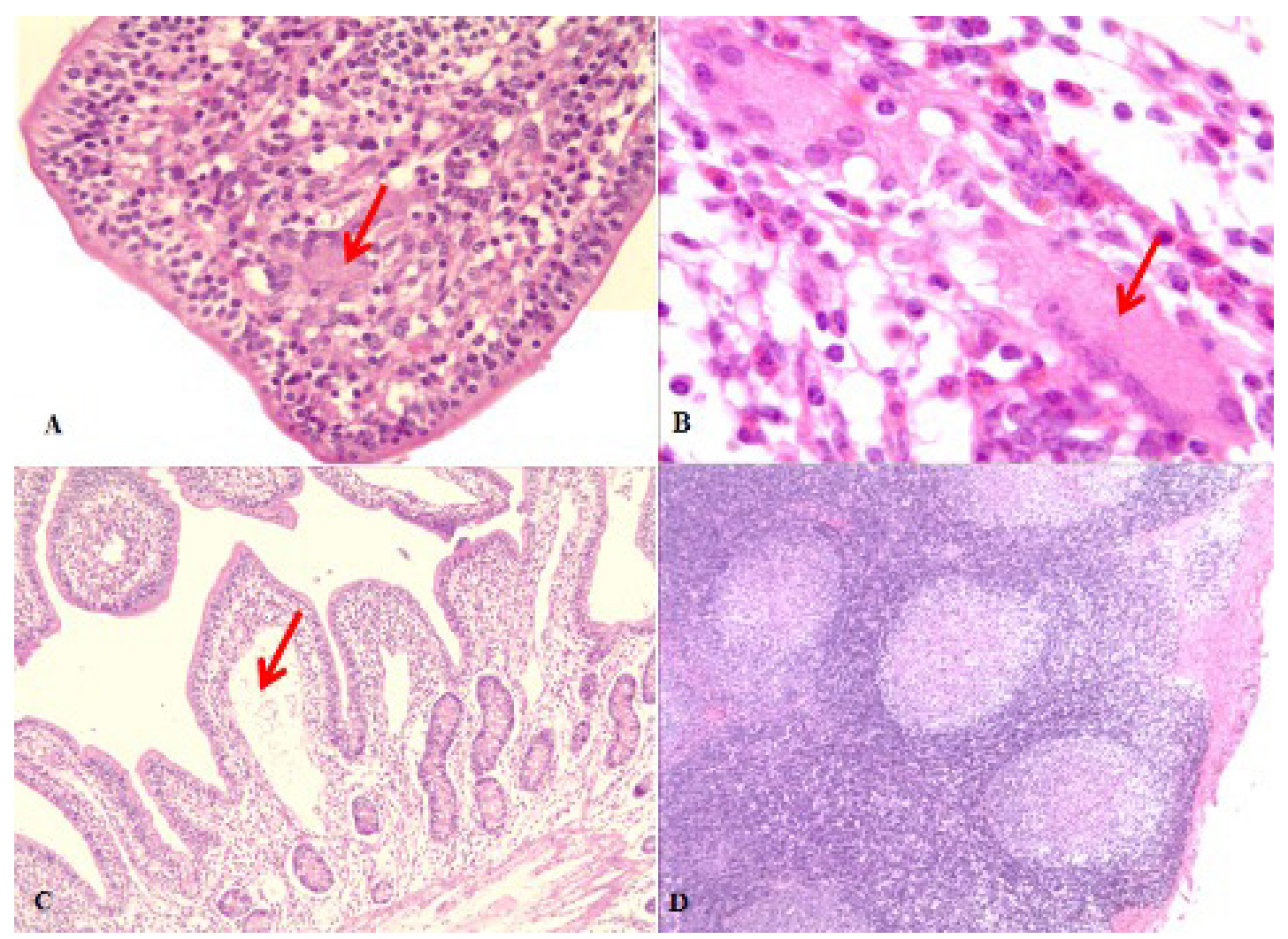

Figure 2. Histopathological findings of the tissue samples collected from all groups of calves. A: Langerhans-type giant cell on lamina propria of intestinal villi, calf \#041117, group B, 40X HE. B: a more detailed Langerhans-type giant cell on deep lamina propria, calf \#021117, group B (B), 60X HE. C: lymphangitis and lymphatic vessels dilatation in the center of the intestinal villi. Calf \#031117, group B, 10X HE. D: activation of cortical germinal centers in mesenteric lymph node. Calf \#021017, group B, 10X HE. 
Table 2. Histopathological findings.

\begin{tabular}{|c|c|c|c|c|c|c|}
\hline Group & Calf & Intestine & $\begin{array}{l}\text { Mesenteric } \\
\text { lymph node }\end{array}$ & Ileo-cecal valve & $\begin{array}{l}\text { Ileo-cecal lyphm } \\
\text { node }\end{array}$ & $\begin{array}{l}\text { Ziehl- } \\
\text { Nielsen }\end{array}$ \\
\hline A & 021017 & Eosinophils $(+++)$ & - & Eosinophils $(++)$ & $\begin{array}{l}\text { Active germ } \\
\text { centers }(++)\end{array}$ & - \\
\hline A & 270817 & Eosinophils (++) & $\begin{array}{l}\text { Active germ } \\
\text { centers }(++)\end{array}$ & $\begin{array}{c}\text { Eosinophils }(+) \\
\text { Active Peyer's patches germ } \\
\text { centers }(++)\end{array}$ & $\begin{array}{l}\text { Active germ } \\
\text { centers }(++)\end{array}$ & - \\
\hline A & 050917 & $\begin{array}{c}\text { Eosinophils }(++) \\
\text { Active Peyer's patches germ } \\
\text { centers }(+)\end{array}$ & $\begin{array}{l}\text { Active germ } \\
\text { centers }(+)\end{array}$ & $\begin{array}{c}\text { Eosinophils }(+) \\
\text { Active Peyer's patches germ } \\
\text { centers }(++)\end{array}$ & $\begin{array}{l}\text { Active germ } \\
\text { centers }(+)\end{array}$ & - \\
\hline A & 300917 & $\begin{array}{c}\text { Eosinophils }(+) \\
\text { Active Peyer's patches germ } \\
\text { centers }(+)\end{array}$ & $\begin{array}{l}\text { Active germ } \\
\text { centers }(+)\end{array}$ & $\begin{array}{c}\text { Eosinophils }(+) \\
\text { Active Peyer's patches germ } \\
\text { centers }(++)\end{array}$ & $\begin{array}{l}\text { Active germ } \\
\text { centers }(++)\end{array}$ & - \\
\hline A & 011017 & $\begin{array}{c}\text { Eosinophils }(++) \\
\text { Active Peyer's patches germ } \\
\text { centers }(+) \\
\text { Macrophages in Peyer's patches } \\
(+)\end{array}$ & $\begin{array}{l}\text { Active germ } \\
\text { centers }(+)\end{array}$ & $\begin{array}{c}\text { Eosinophils }(+) \\
\text { Active Peyer's patches germ } \\
\text { centers }(+)\end{array}$ & $\begin{array}{l}\text { Active germ } \\
\text { centers }(+)\end{array}$ & - \\
\hline B & 311017 & $\begin{array}{c}\text { Eosinophils }(+) \\
\text { Lymphatic vessel dilation in } \\
\text { lamina propria } \\
\text { propia }(+) \\
\text { Langhans-type giant cells }(+)\end{array}$ & $\begin{array}{l}\text { Active germ } \\
\text { centers }(+)\end{array}$ & $\begin{array}{c}\text { Eosinophils }(+) \\
\text { Active Peyer's patches germ } \\
\text { centers }(++)\end{array}$ & $\begin{array}{l}\text { Active germ } \\
\text { centers }(++)\end{array}$ & - \\
\hline B & 011117 & $\begin{array}{c}\text { Eosinophils }(+) \\
\text { Lymphatic vessel dilation in } \\
\text { lamina propria }(+) \\
\text { Macrophages in Peyer's patches } \\
(+)\end{array}$ & $\begin{array}{l}\text { Active germ } \\
\text { centers }(+)\end{array}$ & Eosinophils (+) & $\begin{array}{l}\text { Active germ } \\
\text { centers }(++)\end{array}$ & - \\
\hline $\mathrm{B}$ & 021117 & $\begin{array}{l}\text { Langhans-type giant cells }(+) \\
\text { Lymphatic vessel dilation in } \\
\text { lamina propria }(++) \\
\text { Macrophages in } \\
\text { Peyer's patches }(+) \\
\text { Eosinophils }(+)\end{array}$ & $\begin{array}{l}\text { Active germ } \\
\text { centers }(++)\end{array}$ & $\begin{array}{c}\text { Eosinophils }(+) \\
\text { Active Peyer's patches germ } \\
\text { centers }(++)\end{array}$ & $\begin{array}{l}\text { Active germ } \\
\text { centers }(++)\end{array}$ & - \\
\hline B & 031117 & $\begin{array}{c}\text { Eosinophils }(++) \\
\text { Langhans-type giant cells }(+) \\
\text { Lymphatic vessel dilation in } \\
\text { lamina propria }(++)\end{array}$ & $\begin{array}{l}\text { Active germ } \\
\text { centers }(++)\end{array}$ & $\begin{array}{c}\text { Eosinophils }(+) \\
\text { Langhans-type giant cells }(+)\end{array}$ & $\begin{array}{l}\text { Active germ } \\
\text { centers }(++)\end{array}$ & - \\
\hline B & 041117 & Eosinophils $(++)$ & $\begin{array}{l}\text { Active germ } \\
\text { centers }(++)\end{array}$ & Eosinophils $(++)$ & $\begin{array}{l}\text { Active germ } \\
\text { centers }(++)\end{array}$ & - \\
\hline
\end{tabular}

statistic strength for the analysis with animal welfare for experimental animals.

Therefore, given the findings shown in the present study, we cannot judge the effectiveness of copper ions to block infection transmission and progression without first exploring if copper treatments are selecting for more virulent MAP strains, as described with many antibiotic drugs (Beceiro et al 2013).

\section{ACKNOWLEDGEMENTS}

This work was supported by FONDECYT Grant (1161633). Pamela Steuer was the recipient of a Doctoral Studentship from the Chilean government (CONICYT) during the present study which was part of a Doctoral Thesis of the Universidad Austral de Chile. The authors thank very specially Carmen Rivas and Roberto Valdés from the experimental farm, for their participation and help with taking care of the animals, the facilities and restraining animals.

\section{REFERENCES}

Albright JL, Fulwider WK. 2007. Dairy cattle behaviour, facilities, handling, transportation, automation and well-being. In: Grandin $\mathrm{T}$ (ed). Livestock handling and transport. CABI, Wallingford, United Kingdom.

Beceiro A, Tomás M, Bou G. 2013. Antimicrobial resistance and virulence: a successful or deleterious association in the bacterial world? Clin Microbiol Rev 26, 185-230. 
Chiodini RJ, Chamberlin WM, Sarosiek J, McCallum RW. 2012. Crohn's disease and the mycobacterioses: a quarter century later: causation or simple association? Crit Rev Microbiol 38, 52-93.

Corbett C, de Jong M, Orsel K, De Buck J, Barkema HW. 2019. Quantifying transmission of Mycobacterium avium subsp. paratuberculosis among group-housed dairy calves. Vet Res 50, 60.

Dzieciol M, Volgger P, Khol J, Baumgartner W, Wagner M, et al. 2010. A novel real-time PCR assay for specific detection and quantification of Mycobacterium avium subsp. paratuberculosis in milk with the inherent possibility of differentiation between viable and dead cells. BMC Res Notes 3, 251.

Faúndez G, Troncoso M, Navarrete P, Figueroa G. 2004. Antimicrobial activity of copper surfaces against suspensions of Salmonella enterica and Campylobacter jejuni. BMC Microbiol 4, 19.

Grant IR, Ball HJ, Neill SD, Rowe MT. 1996. Inactivation of Mycobacterium paratuberculosis in cows' milk at pasteurization temperatures. Appl Environ Microbiol 62, 2631-2636.

Grant IR, Williams AG, Rowe MT, Muir DD. 2005. Efficacy of various pasteurization time-temperature conditions in combination with homogenization on inactivation of Mycobacterium avium subsp. paratuberculosis in milk. Appl Environ Microbiol 71, 2853-2861.

Grant IR, Foddai A, Tarrant J, Kunkel B, Hartmann FA, et al. 2017. Viable Mycobacterium avium ssp. paratuberculosis isolated from calf milk replacer. J Dairy Sci 100, 9723-9735.

Greig A, Stevenson K, Henderson D, Perez V, Hughes V, et al. 1993. Epidemiological study of paratuberculosis in wild rabbits in Scotland. J Clin Microbiol 37, 1746-1751.

Harris NB, Barletta RG. 2001. Mycobacterium avium subsp. paratuberculosis in Veterinary Medicine. Clin Microbiol Rev 14, 489-512.

Manning EJ, Collins MT. 2001. Mycobacterium avium subsp. paratuberculosis: pathogen, pathogenesis and diagnosis. Rev Sci Tech Int Off Epi 20, 133-150.

Mehtar S, Wiid I, Todorov SD. 2008. The antimicrobial activity of copper and copper alloys against nosocomial pathogens and Mycobacterium tuberculosis isolated from healthcare facilities in the Western Cape: an in vitro study. J Hosp Infect 68, 45-51.

Mitchell RM, Medley GF, Collins MT, Schukken YH. 2012. A metaanalysis of the effect of dose and age at exposure on shedding of Mycobacterium avium subspecies paratuberculosis (MAP) in experimentally infected calves and cows. Epidemiol Infect 140, 231-246.

Mortier R, H Barkema, K Orsel, R Wolf, J De Buck. 2014. Shedding patterns of dairy calves experimentally infected with Mycobacterium avium subsp. paratuberculosis. Vet Res 45, 71, 1-9.
Noyce JO, Michels H, Keevil CW. 2006 . Potential use of copper surfaces to reduce survival of epidemic meticillinresistant Staphylococcus aureus in the healthcare environment. J Hosp Infect 63, 289-297.

Noyce JO, Michels H, Keevil CW. 2006 ${ }^{\text {}}$. Use of copper cast alloys to control Escherichia coli $\mathrm{O} 157$ cross-contamination during food processing. Appl Environ Microbiol 72, 4239-4244.

Salgado M, Alfaro M, Salazar F, Troncoso E, Mitchell RM, et al. 2013. Effect of soil slope on appearance of Mycobacterium avium subsp. paratuberculosis in water running off grassland soil after contaminated slurry application. Appl Environ Microbiol 79, 3544-3552.

Steuer P, Avilez C, Tejeda C, González N, Ramírez-Revecco A, et al. 2018. In vitro inactivation of Mycobacterium avium subsp. paratuberculosis (MAP) by use of copper ions. BMC Microbiol 18, 172.

Steuer P, Collado B, Avilez C, Tejeda C, Soto JP, et al. 2019. Is the transmission of Mycobacterium avium subspecies paratuberculosis (MAP) infection through milk intended to feed calves an overlooked item in paratuberculosis control programs? Trop Anim Health Prod $52,89-94$

Steuer P, Tejeda C, Martinez O, Ramirez-Reveco A, González N, et al. 2020. Effectiveness of copper ions against Mycobacterium avium subsp. paratuberculosis and bacterial communities in naturally contaminated raw cow's milk. J Appl Microbiol, doi:10.1111/ jam. 14923.

Stull C, Reynolds J. 2008. Calf welfare. Vet Clin Food Anim 24, 191-203.

Sweeney RW. 1996. Transmission of paratuberculosis. Vet Clin Food Anim 12, 305-312.

Sweeney RW. 2011. Pathogenesis of paratuberculosis. Vet Clin Food Anim 27, 537-546.

Warnes SL, Green SM, Michels HT, Keevil CW. 2010. Biocidal efficacy of copper alloys against pathogenic enterococci involves degradation of genomic and plasmid DNAs. Appl Environ Microbiol 76, 5390-5401.

Weaver L, Noyce JO, Michels HT, Keevil CW. 2010. Potential action of copper surfaces on meticillin-resistant Staphylococcus aureus. J Appl Microbiol 109, 2200-2205.

Whan LB, Grant IR, Ball HJ, Scott R, Rowe MT. 2001. Bactericidal effect of chlorine on Mycobacterium paratuberculosis in drinking water. Lett Appl Microbiol 33, 227-231.

Wilks SA, Michels H, Keevil CW. 2005. Survival of Escherichia coli O157 on a range of metal surfaces. Int J Food Microbiol 105, 445-454.

Windsor PA, Whittington RJ. 2010. Evidence for age susceptibility of cattle to Johne's disease. Vet $J$ 184, 37-44.

Wolschendorf F, Ackart D, Shrestha T, Hascall-Dove L, Nolan S, et al. 2011. Copper resistance is essential for virulence of Mycobacterium tuberculosis. PNAS 108, 1621-1626. 